\title{
MENGEDUKASI MASYARAKAT DALAM UPAYA PENCEGAHAN COVID-19 DAN PENCEGAHAN KEBAKARAN HUTAN DAN LAHAN DI DESA SAKA KAJANG
}

\author{
Whendy Trissan ${ }^{1}$, Rinto Alexandro $^{2}$, Revianti Coenraad ${ }^{3}$, Wahidin $^{4}, \operatorname{Rachmad~Persada}^{5}$, \\ Siswanto $^{6}$, Seli Sepiyanty ${ }^{7}$, Nofriza Ismerella Simarmata ${ }^{8}$, Kasepta Agrapta ${ }^{9}$, Seroja Puji \\ Astuti $^{10}$, Purnama Sari ${ }^{11}$, Ahmad Yusdi Fahrizal ${ }^{12}$, Sandria Samosir ${ }^{13}$, Bella Septriana ${ }^{14}$, Singgih \\ Pranowo ${ }^{15}$, Pija Ramadani ${ }^{16}$, Evriandy ${ }^{17}$, Dian Meliani Kusuma Dewi ${ }^{18}$, Titi Nor Amalia ${ }^{19}$, \\ Shepri Ranggala ${ }^{20}$ \\ Universitas Palangka Raya \\ *E-mail: rinto.alexandro@fkip.upr.ac.id
}

\begin{abstract}
ABSTRAK
Kegiatan pengabdian pada masyarakat dimaksudkan untuk memberikan solusi terhadap permasalahan nyata yang terjadi pada masyarakat dalam upaya pencegahan covid-19 dan pencegahan kebakaran hutan dan lahan di desa Saka Kajang. Asap kebakaran hutan dan lahan dapat menyebabkan sistem kekebalan tubuh menurun sehingga rentan terhadap berbagai infeksi dan penyakit terutama penyakit pada saluran pernapasan. Penyakit-penyakit yang berhubungan dengan paparan asap tersebut juga bisa menjadi komorbid atau penyakit penyerta yang memberatkan Covid-19. Selain itu risiko terinfeksi Covid-19 juga semakin meningkat, karena faktor imun berperan penting pada Covid-19. Metode pengbadian kepada masyarakat ini yaitu Kegiatan Kuliah Kerja Nyata Tematik (KKN-T) Universitas Palangka Raya periode II Tahun 2020 untuk kelompok 53 dilaksanakan di Desa Saka Kajang, Kecamatan Jabiren Raya, Kabupaten Pulang Pisau. Kegiatan ini terhitung mulai 7 Agustus hingga 7 September 2020. Keberhasilan pada kegiatan ini yaitu: Tumbuhnya kesadaran masyarakat Desa Saka Kajang untuk melaksanakan protokol kesehatan pencegahan covid-19 dalam kehidupan sehari-hari. Tumbuhnya kesadaran masyarakat Desa Saka Kajang untuk tidak membakar hutan dan lahan. Tumbuhnya kesadaran masyarakat Desa Saka Kajang untuk memaksimalkan penggunaan pekarangan rumah dengan menanam sayuran menggunakan media hidroponik
\end{abstract}

Kata Kunci: Corona Virus, Kebakaran Hutan, Ekonomi Masyarakat

\section{EDUCATING THE COMMUNITY IN EFFORTS TO PREVENT COVID- 19 AND PREVENTION OF LAND AND FOREST FIRE IN SAKA KAJANG VILLAGE}

\begin{abstract}
Community service activities are intended to provide solutions to real problems that occur in the community in efforts to prevent Covid-19 and prevent forest and land fires in the village of Saka Kajang. The smoke from forest and land fires can cause the immune system to decline, making it susceptible to various infections and diseases, especially diseases of the respiratory tract. Diseases associated with smoke exposure can also be comorbid or comorbidities that aggravate Covid-19. In addition, the risk of being infected with Covid-19 is also increasing, because immune factors play an important role in Covid-19. This community service method, namely the Thematic Real Work Lecture Activity (KKN-T) of Palangka Raya University period II of 2020 for group 53 was held in Saka Kajang Village, Jabiren Raya District, Pulang Pisau Regency. This activity starts from 7 August to 7 September 2020. The success of this activity is: The growing awareness of the people of Saka Kajang Village to implement the health protocol for preventing Covid-19 in their daily life. The growing awareness of the people of Saka Kajang Village not to burn the forest and land. The growing awareness of the people of Saka Kajang Village to maximize the use of the house yard by growing vegetables using hydroponic media.
\end{abstract}

Keywords: Corona Virus, Forest Fire, Community Economy 
BAKTI BANUA : Jurnal Pengabdian Kepada Masyarakat

Volume 2 No. 1 Mei 2021

e-ISSN : 2722-3736

p-ISSN : 2722-7529

https://ejurnal.stimi-bjm.ac.id/index.php/BBJM/

\section{PENDAHULUAN}

Penyakit virus corona (COVID-19) adalah penyakit menular yang disebabkan oleh coronavirus yang paling baru ditemukan. Virus dan penyakit baru ini diketahui setelah menyebar yang kemunculannya dimulai di Wuhan, Cina, pada bulan Desember 2019. Penyakit jenis baru ini belum pernah diidentifikasi pada manusia. Virus corona adalah zoonosis, artinya ditularkan antara hewan dan manusia. Kasus positif COVID-19 di Indonesia pertama kali dideteksi pada 2 Maret 2020, ketika dua orang terkonfirmasi tertular dari seorang warga negara Jepang. Pada 9 April, pandemi sudah menyebar ke 34 provinsi dengan DKI Jakarta, Jawa Timur, dan Jawa Tengah sebagai provinsi paling terpapar. Sedangkan di Kalimantan Tengah pandemi COVID-19 pertama kali terdeteksi pada 20 Maret 2020 di kota Palangka Raya. Kasus COVID-19 sudah menyebar ke semua kabupaten dan kota. Sampai dengan 13 September 2020 terdapat 2.966 kasus di Kalimantan Tengah. Selain itu, menurut BMKG Kalteng menyebutkan bahwa perkiraan musim kemarau pada tahun 2020 ini secara keseluruhan wilayah Kalimantan Tengah, akan terjadi puncak musim kemarau pada bulan Juli hingga bulan September 2020. Berlangsungnya kemarau pada rentang waktu tersebut akan berpotensi meningkatkan kemungkinan terjadinya Karhutla atau kebakaran hutan dan lahan yang akan menimbulkan kabut asap. Asap kebakaran hutan dan lahan dapat menyebabkan sistem kekebalan tubuh menurun sehingga rentan terhadap berbagai infeksi dan penyakit terutama penyakit pada saluran pernapasan. Penyakit-penyakit yang berhubungan dengan paparan asap tersebut juga bisa menjadi komorbid atau penyakit penyerta yang memberatkan Covid-19. Selain itu risiko terinfeksi Covid-19 juga semakin meningkat, karena faktor imun berperan penting pada Covid-19. Adanya pandemi COVID-19 ini mengharuskan masyarakat untuk menjalankan protokol kesehatan terutama mengurangi aktivitas diluar rumah. Hal ini berdampak pada perekonomian, terutama perekonomian masyarakat dengan ekonomi menengah kebawah yang kebanyakan pekerjaannya mengharuskan mereka berada diluar rumah dan berinteraksi dengan banyak orang seperti buruh pabrik dan pedagang kecil. Pada penyelenggaraan KKN-T Periode II UPR Tahun 2020 ini, diambil sebuah Tema yang akan digunakan yaitu "Peningkatan Keterlibatan Masyarakat Dalam Upaya Pencegahan Kebakaran Lahan dan Hutan, Penyebaran Covid-19 dan Pengembangan Ketahanan Pangan". Dari tema yang diberikan, kelompok 53 KKN-T Periode II UPR Tahun 2020 yang dilaksanakan di Desa Kajang Kecamatan Jabiren Raya Kabupaten Pulang Pisau akan mengambil judul "Mengedukasi masyarakat dalam upaya pencegahan Covid-19 dan kebakaran hutan dan lahan serta pemaksimalan pemanfaatan pekarangan rumah untuk ketahanan pangan guna meningkatkan perekonomian“ yang diharapkan akan membantu masyarakat untuk lebih memahami mengenai keadaan pandemic yang sedang terjadi sekarang dan mengurangi resiko terjadinya pandemic yang lebih parah lagi. Edukasi merupakan kebutuhan yang sangat penting bagi kehidupan manusia, sudah semestinya usaha dalam menumbuh kembangkan edukasi secara sistematis dan berkualitas selalu di upayakan, sehingga tujuan dari proses edukasi dapatdi capai secara optimal. Dalam konteks relasi sosisal, khususnya dalam relasi antara masyarakat yang membutuhan pendidikan pada tingkat tertentu melaluipendidikan formal dan pemerintah sebagai penyedia kebutuhan itu terdapat semacam yang menjadi pengikat dalam relasi tersebut. Hubungan antara masyarakat dan pemerintah dengan salah satukebutuhan atas pendidikan di pahami dalam konteks organisasi, keberadaannya dapat dilihat dari sudut pandang jaringan sosial dalam suatu organisasi sosial (Agusyanto, 2007). Virus Corona atau severe acute respiratory syndrome corona virus 2 (SARS-Cov-2) adalah virus yang menyerang sistem pernapasan. Corona virus merupakan keluarga besar virus yang menyebabkan penyakiit pada manusia dan hewan. Pada manusia biasanya menyebabkan penyakit ifeksi saluran pernafasan, mulai dari flu biasa hingga penyakit yang serius seperti Middle East Respiratory Syndrome (MERS) dan sindrom pernafasan Akut Berat/ Severe Acute Respiratory Syndrome (SARS). Coronavirus jenis baru yang ditemukan pada manusia sejak kejaadian luar biasa muncul di Wuhan, China pada Desember 2019 kemudian di beri nama Severe Acute Respiratory Syndrome Corona virus 2 (SARS-COV2), dan menyebabkan penyakit Coronavirus Disease-2019 (COVID-19).

Kebakaran hutan dibedakan dengan kabakaran lahan. Kebakaran hutan yaitu kebakaran yang terjadi di dalam kawasan hutan, sedangkan kebakaran lahan adalah kebakaran yang terjadi di luar kawasan hutan dan keduanya bisa terjadi baik di sengaja maupun tanpa sengaja (Hatta, 2008). Kebakaran hutan ialah terbakarnya sesuatu yang menimbulkan bahaya atau mendatangkan bencana. Kebakaran dapat terjadi karena pembakaran yang tidak di kendalikan, karena proses spontan alami, 
atau karena kesengajaan. Proses alami sebagai contohnya kilat yang menyambar pohon atau bangunan, letusan gunung api yang menebarkan bongkahan bara api, dan gesekan antara ranting tumbuhan kering yang mengandung minyak karena goyangan angin yang menimbulkan panas atau percikan api (Notohadinegoro, 2006). Menurut Darwiyati dan Tuheteru (2010) di Indonesia, kebakaran hutan dan lahan hampir 99\% diakibatkan oleh kegiatan manusai baik di sengaja maupun tidak (unsure kelalaian). Di antara angka persentase tersebut, kegiatan konspersi lahan menyumbang 34\%, peladangan liar $25 \%$, pertanian $17 \%$, kecemburuan sosial $14 \%$, proyek transmigrasi $8 \%$, sedangkan hanya $1 \%$ yang di sebabkan oleh alam. Faktor lain yang menjadi penyebab semakin hebatnya kebakaran hutan dan lahan sehingga menjadi pemicu kebakaran adalah iklim yang ekstrim, sumber energy berupa kayu, deposit batu bara dan gambut. Ketahanan Pangan merupakan ketersediaan pangan dan kemampuan seseorang untuk mengaksesnya. Sebuah rumah tangga dikatakan memiliki katahan pangan jika penghuninya tidak berada dalam kondisi kelaparan atau dalam ancaman kelaparan. Ketahanan pangan merupakan ukuran kelentingan terhadap gangguan kepada masa depan atau ketiadaan suplai pangan penting akibat berbagai faktor seperti kekeringan, kelangkaan bahan bakar, ketikstabilan ekonomi dan sebagainya. Penilaian ketahanan pangan di bagi menjadi keswadayaan atau keswasembadaan perorangan (self- sufficiency) dan ketergantungan eksternal yang membagi serangkaian faktor risiko. World Health Organization (WHO) Mendefinisikan 3 komponen utama ketahan yaitu ketersediaan pangan, akses pangan, dan pemanfaatan pangan. Ketersediaan pangan adalah kemampuan memiliki sejumlah pangan yang cukup untuk kebutuhan dasar. akses pangan adalah kemampuan memiliki sumber daya secara ekonomi maupun fisik untuk mendapatkan bahan pangan bernutrisi. Pemanfaatan pangan adalah kemampuan dalam memanfaatkan bahan pangan dengan benar dan tepat secara proporsional.

\section{METODE}

Kegiatan Kuliah Kerja Nyata Tematik (KKN-T) Universitas Palangka Raya periode II Tahun 2020 untuk kelompok 53 dilaksanakan di Desa Saka Kajang, Kecamatan Jabiren Raya, Kabupaten Pulang Pisau. Kegiatan ini terhitung mulai 7 Agustus hingga 7 September 2020. KKN-T periode II tahun 2020 dilaksanakan berdasarkan tema yang telah ditentukan, yaitu Peningkatan Keterlibatan Masyarakat dalam Upaya Pencegahan Kebakaran Lahan dan Hutan, Penyebaran Covid-19 dan Pengembangan Ketahanan Pangan. Adapun program prioritas dari kelompok KKN-T Desa Saka Kajang, Kecamatan Jabiren Raya, Kabupaten Pulang Pisau, yaitu: 1) Memberikan edukasi mengenai pencegahan penyebaran Covid-19 pada masyarakat di Desa Saka Kajang, Kecamatan Jabiren Raya, Kabupaten Pulang Pisau. 2) Mengkampanyekan tentang bahaya kebakaran hutan dan lahan pada masyarakat di Desa Saka Kajang, Kecamatan Jabiren Raya, Kabupaten Pulang Pisau. 3) Memberikan pendampingan kepada masyarakat guna mendukung pengembangan UMK dan ketahanan pangan di Desa Saka Kajang, Kecamatan Jabiren Raya, Kabupaten Pulang Pisau. Metode dasar pelaksanaan KKN Tematik ini dilaksanakan selama kurang lebih selama 4 minggu yang terbagi dalam tiga tahap yaitu: Sosialisasi dan perijinan, Perencanaan dan Persiapan, Pelaksanaan.

Pengumpulan data dalam pelaksanaan KKN-T di Kecamatan Jabiren Raya, Kabupaten Pulang Pisau, Desa Saka Kajang dilakukan dengan cara sebagai berikut: Pengamatan adalah alat pengumpulan data yang dilakukan dengan cara mengamati dan mencatat secara sistematik gejalagejala yang ada di Kecamatan Jabiren Raya, Kabupaten Pulang Pisau, Desa Saka Kajang Pada metode pengamatan ini, mahasiswa terjun langsung untuk mengamati secara langsung fenomena-fenomena sosial serta hal-hal lain yang terjadi di Desa Saka Kajang terkait dengan program kerja yang akan dilaksanakan. Metode interview merupakan suatu metode pengumpulan data yang dilakukan melalui tanya jawab secara langsung dengan sumber data. Interview merupakan alat pengumpulan informasi dengan cara mengajukan pertanyaan secara lisan, untuk dijawab secara lisan pula. Kegiatan interview ini dilakukan oleh mahasiswa terhadap informan yang menjadi obyek dari kegiatan KKN-T, yaitu Kepala Desa, Para Perangkat Desa, dan Masyarakat Desa Saka Kajang.Wawancara ini bertujuan untuk memperoleh informasi yang ada relevansinya dengan pokok persoalan kegiatan KKN-T kelompok 53 di Desa Saka Kajang. 


\section{HASIL DAN PEMBAHASAN}

Rencana Program

Adapun rencana program yang akan dijalankan kelompok KKN-T desa Saka Kajang Kabupaten Pulang Pisau yaitu:

1. Pencegahan dan Penanggulangan Kebakaran Lahan dan Hutan

a. Pembasahan kanan dan kiri jalan trans Kalimantan

b. Relawan penyuluhan pencegahan kebakaran

c. Pembuatan dan pemasangan spanduk pencegahan kebakaran hutan dan lahanPengembangan Protokol COVID-19 di Perdesaan

2. Relawan pencegahan penyebaran COVID-19
a. Pelatihan dan pendampingan pembuatan hand sanitizer, masker, face shield berbahan local
b. Penyemprotan disinfektan ke rumah ibadah
c. Pembagian serta pemasangan poster dan spanduk pentingnya pencegahan covid-19

3. Pemanfaatan Lahan Pekarangan Sebagai Sumber Ketahanan Pangan Rumah Tangga Untuk Pengembangan Usaha Mikro dan Kecil (UMK)

a. Pelatihan dan pendampingan budidaya dan pasca panen tanaman hidroponik

b. Pemanfaatan sosial media dalam pemasaran hasil budidaya tanaman hidroponik

\section{Kondisi Awal Lokasi dengan Foto Foto Kegiatan}
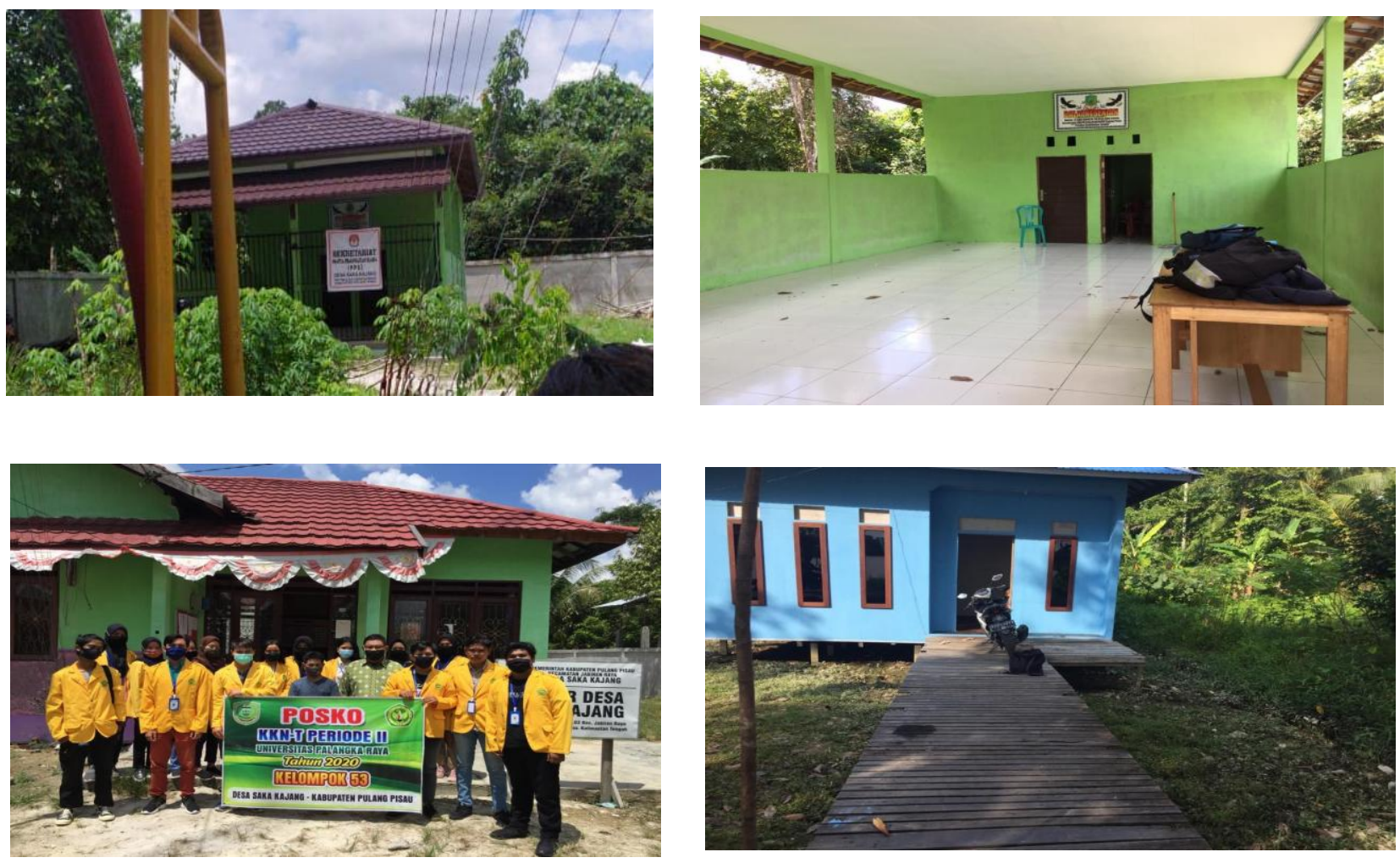

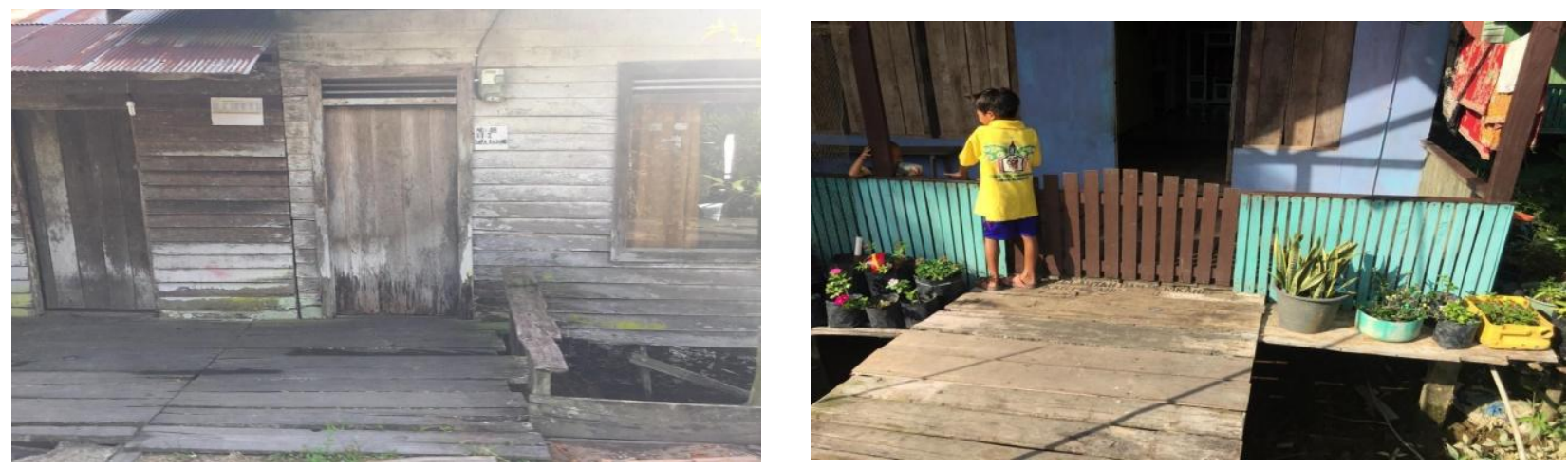

Gambar 1. Pekarangan Rumah Warga Desa Saka Kajang

\section{Permasalahan yang Ditemukan}

Permasalahan yang kami temukan selama 1 minggu pelaksanaan, yaitu: Kurangnya kesadaran masyarakat tentang bahaya Covid-19. Kurangnya tempat/fasilitas tempat pembuangan sampah. Kurangnya kesadaran masyarakat dalam mengolah lahan untuk program ketahanan pangan. Kurangnya minat masyarakat dalam upaya peningkatan UMK (Usaha Mikro Kecil). Tidak terdapat posko dan himbauan penanganan kebakaran hutan dan lahan (karhutla).

\section{Pelaksanaan Kegiatan}

Sesuai dengan 4 program kerja wajib, kami membagi 1 program kerja untuk di selesaikan per minggu.

\section{Minggu Pertama (Covid-19)}

Minggu Pertama tanggal 7-14 Agustus 2020 kami menyelesaikan program kerja Covid-19, adapun program kerjanya yaitu pembuatan dan pembagian masker, pembuatan dan pembagian hand sanitizer, pembuatan dan penyemprotan disinfektan, kemudian pembuatan face shield. Pada kegiatan pembuatan Hand Sanitizer alami bahan yang diperlukan adalah Daun Sirih, Jeruk Nipis, dan Air Bersih. Sedangkan untuk alat yang digunakan adalah panci yang digunakan untuk merebus daun sirih dengan air, lalu ada pisau dan gunting yang digunakan untuk memotong daun sirih yang akan direbus. Selanjutnya ada saringan yang digunakan untuk menyaring hasil Hand Sanitizer yang sudah dibuat. Setelah itu hasil penyaringan Hand Sanitizer dimasukan ke dalam Botol Spray yang digunakan sebagai tempat Hand Sanitizer. Setelah kegiatan pembuatan Hand Sanitizer maka diadakan pembagian Hand Sanitizer sekaligus Masker pada acara Posyandu bulanan. Pembagian Hand Sanitizer dan masker ini bertujuan untuk mengingatkan masyarakat Desa Saka Kajang agar tetap waspada terhadap Covid- 19 dengan tetap menjaga kebersihan tangan serta mengurangi resiko terpapar virus melalui area wajah. Kegiatan pada Subtema Covid-19 yang dilaksanakan berikutnya adalah pemasangan poster dan spanduk himbauan waspada Covid-19. Pada poster dan spanduk tersebut dijelaskan mengenai bagaimana cara mencegah untuk tidak terjangkit Covid-19 dan juga bagaimana gejala yang terjadi saat terjangkit Covid-19. Spanduk tersebut dipasang di pemukiman rumah warga dan poster ditempel di warung warung sehingga dapat dengan mudah dibaca oleh warga. Selanjutnya setelah pemasangan poster dan spanduk himbauan waspada Covid-19, kegiatan yang dilaksanakan adalah penyemprotan desinfektan pada rumah ibadah yang ada di Desa Saka Kajang. Setelah itu kegiatan yang dilaksanakan adalah kampanye waspada Covid-19. Kampanye tersebut dilaksanakan dengan berkeliling Desa Saka Kajang dan menyerukan kata kata ajakan untuk mengikuti Protokol kesehatan dalam mencegah penyebaran lebih luas Covid-19.

\section{Minggu Kedua (Ketahanan Pangan)}

Minggu kedua tanggal 15-21 Agustus 2020 kami menjalankan program kerja ketahanan pangan, kami memilih ketahanan pangan karena pertumbuhan bibit memerlukan waktu sekitar 2-3 minggu. Pada sub tema pemanfaatan pekarangan sebagai sumber ketahanan pangan kegiatan yang 
dilakukan adalah pembuatan hidroponik sebagai alternatif pemanfaatan lahan pekarangan, penanaman sayuran dalam polybag, dan pembuatan mini garden di samping posko/ balai kesenian. Pembuatan hidroponik dipilih dikarenakan mayoritas masyarakat desa Saka Kajang tinggal di pinggiran sungai Kahayan sehingga pekarangan rumah warga lebih cocok untuk menggunakan media hidroponik daripada penanaman tanaman langsung pada tanah. Sedangkan untuk sebagian warga yang tinggal di daerah jalan trans Kalimantan dengan kondisi pekarangan yang sering tergenang oleh pasang surut air sungai lebih cocok untuk menggunakan media tanam polybag. Setelah itu dibuat mini garden yang berfungsi untuk menyimpan tanaman yang sudah ditanam baik menggunakan media tanam hidroponik maupun media tanam polybag. Setelah itu dilakukan pertemuan untuk menjelaskan kepada masyarakat mengenai cara pembuatan media tanam dan mini garden dalam hal ini dilakukan dengan guru TK yang ada di Desa Saka Kajang.

\section{Minggu ketiga (KARHUTLA)}

Minggu ketiga tanggal 22-29 Agustus 2020 kami menjalankan program kerja karhutla, mulai dari pemasangan spanduk sampai pembasahan kanan kiri jalan Trans Kalimantan. Pada sub tema Kebakaran Hutan dan Lahan dilakukan kegiatan pemasangan spanduk himbauan untuk tidak membakar hutan dan lahan. Selain itu dilaksanakan juga pembasahan kanan dan kiri jalan yang dilaksanakan di perbatasan desa Saka Kajang dan desa Jabiren. Selanjutnya dilaksanakan juga kegiatan kampanye Karhutla untuk menghimbau masyarakat untuk tidak membakar hutan dan lahan serta menjaga hutan.

\section{Minggu keempat (UMK)}

Minggu keempat tanggal 30 agustus - 4 september 2020 kelompok KKN-T Desa Saka Kajang menjalankan program kerja UMK, yaitu membuat kerupuk ketumbar. Pada sub tema Usaha Mikro Kecil kegiatan yang dilakukan adalah mengolah produk yang dibuat dengan memanfaatkan keterampilan masyarakat desa Saka Kajang yaitu membuat Kerupuk Ketumbar. Kemudian produk tersebut dijadikan sebagai Usaha Mikro Kecil yang digunakan untuk penghasilan tambahan masyarakat desa Saka Kajang.

\section{Peran dan Partisipasi Masyarakat}

Masyarakat Desa Saka Kajang menyambut baik kedatangan mahasiswa UPR untuk melaksanakan Kuliah Kerja Nyata Tematik. Pihak Kelurahan memberikan ruang kepada mahasiswa KKN untuk berpartisipasi dengan masyarakat dalam pencegahan Covid-19, Karhutla serta Pengembangan Ketahanan Pangan dan UMK. Berkaitan dengan program-program yang dikerjakan, masyarakat sangat antusias membantu dan selalu melakukan komunikasi setiap berlangsungnya program kegiatan. Masyarakat juga membantu melaksanakan program secara fisik, sehingga pengerjaan program dapat lebih cepat terselesaikan. Tentu saja peran dan partisipasi masyarakat sangat kami butuhkan, tanpa adanya kerjasama yang baik dengan masyarakat setempat kami tidak akan mampu menjalankan program kerja. Beberapa kegiatan selalu melibatkan masyarakat, seperti pembagian masker, hand sanitizer, penyiraman kanan kiri jalan Trans Kalimantan, pembuatan kerupuk ketumbar, bahkan program kerja tambahan seperti acara 17 agustus.

\section{Faktor Pendukung dan Penghambat}

Faktor pendukung yang kami dapatkan di desa saka kajang yaitu kami disambut baik oleh kepala desa, perangkat desa, dan warga setempat, kemudian perangkat desa juga bersedia membantu kami dalam menjalankan program kerja. Faktor penghambat yang kami dapatkan yaitu jaringan yang tidak mendukung, fasilitas yang kurang memadai, dan jarak posko yang jauh dari perumahan warga.

\section{Upaya Mengatasi Hambatan}

Upaya kami dalam mengatasi masalah jaringan adalah kami mencari tempat yang jaringannya bagus, kemudian untuk fasilitas kami menggunakan fasilitas yang ada dan meminjam fasilitas yang ada di kantor desa, guna memperlancar program kerja yang kami jalankan. Dan untuk mengatasi 
hambatan jarak yang lumayan jauh dari posko ke perumahan warga kami bergantian menggunakan motor agar bisa melakukan pendekatan dengan warga.

\section{Keberhasilan Program}

Keberhasilan program kerja kami bisa dikatakan berjalan dengan lancar, karena adanya dukungan warga setempat dan kerja sama kelompok. Beberapa indikator yang mennetukan keberhasilan program kerja kami, yaitu: Tumbuhnya kesadaran masyarakat Desa Saka Kajang untuk melaksanakan protokol kesehatan pencegahan covid-19 dalam kehidupan seharihari. Tumbuhnya kesadaran masyarakat Desa Saka Kajang untuk tidak membakar hutan dan lahan. Tumbuhnya kesadaran masyarakat Desa Saka Kajang untuk memaksimalkan penggunaan pekarangan rumah dengan menanam sayuran menggunakan media hidroponik.

\section{SIMPULAN}

Dari kegiatan Kuliah Kerja Nyata Tematik atau KKN-T periode II UPR Tahun 2020 yang dilaksanakan di desa Saka Kajang, dapat disimpulkan beberapa hal yang terkait dengan program kerja yang sudah dilaksanakan selama 1 bulan kemarin. Program kerja yang dilakukan oleh kelompok 53 di Desa Saka Kajang diambil dari tema yang diberikan yaitu "Peningkatan Keterlibatan Masyarakat Dalam Upaya Pencegahan Kebakaran Lahan dan Hutan, Penyebaran Covid-19 dan Pengembangan Ketahanan Pangan". Dari tema tersebut kami mengambil beberapa kegiatan yang relevan dengan tema yang ada. Pada sub tema Covid-19 dilakukan kegiatan pembuatan dan pembagian hand sanitizer kepada masyarakat desa, pembuatan dan pembagian masker, penyemprotan desinfektan di rumah ibadah, penempelan poster waspada Covid-19 di rumah rumah warga serta kampanye di pemukiman rumah warga desa Saka Kajang untuk menghimbau warga agar tetap melakukan protocol kesehatan sehingga tidak terjangkit penyakit Covid-19. Pada sub tema Kebakaran Hutan dan Lahan dilakukan kegiatan pemasangan spanduk himbauan untuk tidak membakar hutan dan lahan, pembasahan kanan dan kiri jalan yang dilaksanakan di perbatasan desa Saka Kajang dan desa Jabiren. Selnjutnya dilaksanakan juga kegiatan kampanye Karhutla untuk menghimbau masyarakat untuk tidak membakar hutan dan lahan serta menjaga hutan. Pada sub tema pemanfaatan pekarangan sebagai sumber ketahanan pangan kegiatan yang dilakukan adalah pembuatan hidroponik sebagai alternatif pemanfaatan lahan pekarangan, penanaman sayuran dalam polybag, dan pembuatan mini garden di samping posko/ balai kesenian. Pembuatan hidroponik dipilih dikarenakan mayoritas masyarakat desa Saka Kajang tinggal di pinggiran sungai Kahayan sehingga pekarangan rumah warga lebih cocok untuk menggunakan media hidroponik daripada penanaman tanaman langsung pada tanah. Sedangkan untuk sebagian warga yang tinggal di daerah jalan trans Kalimantan dengan kondisi pekarangan yang sering tergenang oleh pasang surut air sungai lebih cocok untuk menggunakan media tanam polybag. Pada sub tema Usaha Mikro Kecil kegiatan yang dilakukan adalah mengolah produk yang dibuat dengan memanfaatkan keterampilan masyarakat desa Saka Kajang yaitu membuat Kerupuk Ketumbar. Kemudian produk tersebut dijadikan sebagai Usaha Mikro Kecil yang digunakan untuk penghasilan tambahan masyarakat desa Saka Kajang. Program kerja yang dilaksanakan tersebut dilakukan bersama dengan masyarakat desa dan pemerintah desa Saka Kajang. Pemerintah desa Saka Kajang sangat membantu semua kegiatan yang dilaksanakan oleh kelompok KKN-T Periode II UPR Tahun 2020 ini. Sehingga program kerja yang diusulkan dapat berjalan sebagaimana mestinya.

\section{DAFTAR PUSTAKA}

Agusyanto, R. 2007. Jaringan Sosial dalam Organisasi. Jakarta: PT Raja Grafindo Persada.

Darwiati, W. dan F.D. Tuheteru. 2010. Dampak Kebakaran Hutan terhadap Pertumbuhan Vegetasi. Jurnal Mitra Hutan Tanaman. 3(1): 27-32.

Susanti, Elly dkk. 2015. Analisis Ketahan Pangan Rumah Tangga Petani di Desa Ulee Lhat Kecamatan Montasik Kabupaten Aceh Besar. Prodi Agribisnis Universitas Teuku Umar. Volume 1. 
BAKTI BANUA : Jurnal Pengabdian Kepada Masyarakat

Volume 2 No. 1 Mei 2021

e-ISSN : 2722-3736

p-ISSN : 2722-7529

https://ejurnal.stimi-bjm.ac.id/index.php/BBJM/

Hafni, Roswita. Rozali, Ahmad. Analisis Usaha Mikro, Kecil, Dan Menengah (UMKM) Terhadap Penyerapan Tenaga Kerja Di Indonesia. Fakultas Ekonomi Universitas Muhammadiyah Sumatera Utara.

Tacconi, Luca. 2013. Kebakaran Hutan di Indonesia: Penyebab, Biaya dan Implikasi Kebijakan. CIFOR Occasional Paper No. 38(i). Center for International Forestry Research.

2020. Penyakit Virus Corona 2019. Jurnal Respirologi Indonesia. Perhimpunan Dokter Paru Indonesia (PDPI). Volume 40 Nomor 2. 